\title{
Praying together: corporate prayer and shared situations
}

\author{
Cockayne, J. L., Salter, G.
}

\begin{tabular}{|l|l|}
\hline Date of deposit & $15 / 01 / 2019$ \\
\hline Document version & Author's accepted manuscript \\
\hline Access rights & $\begin{array}{l}\text { C } 2019 \text { by the Joint Publication Board of Zygon. This work has } \\
\text { been made available online in accordance with publisher policies } \\
\text { or with permission. Permission for further reuse of this content } \\
\text { should be sought from the publisher or the rights holder. This is } \\
\text { the author created accepted manuscript following peer review and } \\
\text { may differ slightly from the final published version. }\end{array}$ \\
\hline $\begin{array}{l}\text { Citation for } \\
\text { published version }\end{array}$ & $\begin{array}{l}\text { Cockayne, J. L., \& Salter, G. (2019). Praying together: corporate } \\
\text { prayer and shared situations. Zygon, 54(3), 702-730. }\end{array}$ \\
\hline $\begin{array}{l}\text { Link to published } \\
\text { version }\end{array}$ & https://doi.org/10.1111/zygo.12543 \\
\hline
\end{tabular}

Full metadata for this item is available in St Andrews Research

Repository at: https://research-repository.st-andrews.ac.uk/

\begin{tabular}{ll|l|} 
University of & FOUNDED \\
St Andrews & 1413
\end{tabular}




\section{Praying Together: Corporate Prayer and Shared Situations}

\section{Introduction}

On the 26 May 1940, Britain was at a point of crisis. Locked in war with Nazi Germany, British troops were stranded on the beach at Dunkirk. King George VI called for the nation to turn to God in prayer and plead for his assistance. Millions of individuals flocked to churches and queued for hours outside Westminster Abbey to pray together for God's assistance. Whilst undoubtedly many of these individuals were already active in praying regularly for God's protection of their country and troops, there was something importantly different about the mass-scaled coordination of prayer that happened on this day. What followed was the so-called 'miracle of Dunkirk' - a violent storm over the beaches of Dunkirk grounded many of the Luftwaffe, followed by a period of calm in which British civilians united to rescue the troops using fishing boats and small leisure boats. Many saw these events as a direct answer to prayer and a work of God. Whilst these circumstances were extraordinary, the practice of praying together in this way is something that happens on a regular basis across churches all over the country, and indeed, the world, today. Praying together takes many different forms-from small prayer groups in houses, to intercessory prayer in formal church liturgies, to mass-scale prayer gatherings. And whilst we are not aiming to defend the claim that the events at Dunkirk were miraculous or a direct answer to prayer here, we aim to offer one general account of the psychological benefits of corporate prayer which might offer one potential explanation of some of the events that unfolded.

The practice of prayer has been the subject of countless academic books and journal articles in psychology, theology, and philosophy of religion. ${ }^{1}$ Yet, despite recent work in sociology, ${ }^{2}$ anthropology, ${ }^{3}$ and ethnography ${ }^{4}$ on the social dimensions of prayer, much of the theological and philosophical literature focuses only on acts of private communication between individuals and God. In this article we develop a theologically and psychologically informed account of the nature and value of corporate prayer.

The paper proceeds as follows: In the first section, we begin by outlining a theological claim that is made by Vincent Brümmer (1984) and H. H. Farmer (1942), namely, that corporate prayer has potential to be more effective than individual prayer since corporate prayer allows us to engage not only with God, but also with one another. There are many layers to this theological claim - corporate prayer involves participating in a mystical body, united by the actions of the Holy Spirit (Underhill, 1936, 81), as well as participating in various visible manifestations of this metaphysical reality - whether that be in a church congregation, or in a national day of prayer. In this paper, whilst we do not have scope to explore all facets of the nature and value of corporate prayer, we focus our attention on one such area, namely, the social-psychological dimension of corporate prayer. By drawing on this social-psychological literature, we aim to explore the theological claim that praying together might be more effective than praying alone, and how to appropriately understand the idea of "efficiency" in this context.

In the second section we focus on giving an account of what it is to pray together by proposing that shared experiences exist on a scale of 'sharedness'. We begin by considering cases in which participants are physically co-present with one another, which seem most easy to capture as instances of corporate prayer. By drawing on the psychological literature on joint attention (e.g. Moore and Dunham, 1995; Scaife and Bruner, 1975), the second-personal perspective (Reddy, 1996; Gómez, 1996), and the philosophical notion of shared situations (Barwise, 1989), we explain what it is for a case of physically co-present prayer to be corporate. We then consider cases that appear less easy to categorise as shared due to their not involving physically co-present participants. Cases such as praying at the same time as a religious community (as in the case of the national day of prayer cited above), praying in a sacred space in which people have prayed for hundreds of years, and praying alongside the communion of 
saints, all appear to share some features with instances of corporate prayer in which there is physical co-presence, but yet, in other respects, there are important differences. By reflecting on these different kinds of praying together, we propose that all share in common a 'sense of sharedness' which can be established through a variety of means (Shteynberg, 2015). ${ }^{5}$ We propose a scale of sharedness, which takes as its strongest examples cases of physically copresent corporate prayer, but which can include cases that are shared in a weaker sense. It is important to flag at this point, that this scale of sharedness refers only to a certain psychological and epistemological account of what it is for a situation to be shared. There are, no doubt, important ways in which our prayer is part of a larger body, even if we do not realise that this is the case. The metaphysics of corporate prayer is another important discussion, but one which we must bracket for another occasion.

In the third and final section, we turn to consider the values of corporate prayer understood as a shared situation. We argue that this kind of shared prayer enables common knowledge of certain truths between participants. As we will explain, shared situations involve multiple levels of alignment, from, what William McNeill (1997) terms 'muscular' coordination of bodies (1997) to alignment of mental states (Gallotti, Fairhurst and Frith, 2017; Tollefson and Dale, 2012). As we will highlight, there have been a number of studies in social psychology that have affirmed and developed these notions of alignment through processes such as imitation and synchronisation, things that we claim can help us to understand the corporate dimension of prayer. Through these aligning processes, participants' attention is focussed to the same target and affiliation between participants increases. Thus, we suggest, one benefit (indeed, there are surely many more benefits which we do not have space to explore here) of understanding corporate prayer as a shared situation is that it establishes and deepens a sense of community in such a way that common purposes and goals might be enacted more effectively.

Before proceeding, we offer some brief words on the nature of the project we are advancing. There are many approaches one might take in drawing together insights from psychology and theology, and indeed there are already many discussions of psychology and prayer. ${ }^{6}$ There is also a growing body of literature addressing corporate prayer, particularly in the psychological literature. For instance, in Spilka and Ladd's (2012) comprehensive study of the psychology of prayer, there is some discussion of corporate prayer. Their approach is much more all-encompassing than the approach we pursue here. Rather than focusing on prayer in general, we give attention to a very specific aspect of corporate prayer. ${ }^{7}$ In this article, we follow the approach advocated by Malcolm Jeeves and Thomas Ludwig (2018) by seeking to engage in a constructive dialogue between psychology and theology, with each field offering complementary insights and enrichments into religious issues. Thus, our psychologically informed account of why certain forms of corporate prayer might be effective is seeking neither to replace theological reflection on this issue nor to provide neat or convenient concordism between the findings of psychology research and Christian teachings. Rather, we suggest, focusing on certain psychological features of corporate prayer can provide fresh insight and enrichment to the question of why corporate prayer is valuable.

\section{The Theology of Praying Together}

Corporate prayer is one of the central practices of the Church. From the early Church (Acts 1:14; 4:23-32), to the present day, almost every Christian tradition and denomination practices some form of praying together. Moreover, in certain traditions of Judaism, community prayer is prioritised over individual prayer; the practice of minyan prayer is an important part of Jewish ritual life but requires at least ten adults to practice. Thus, whilst Christianity is not the only tradition that focuses on corporate prayer, for sake of familiarity and brevity, we focus on Christian examples of prayer here. The Christian tradition clearly affirms both private and corporate acts of prayer. In the Gospel according to Matthew, for instance, Jesus instructs his 
hearers that, 'whenever you pray, go into your room and shut the door and pray to your Father who is in secret' (Matthew 6:6). We can also clearly see Jesus's own practice of praying alone in many places, such as in the garden of Gethsemane (Matthew 26), for example. But yet, many of the Epistles encourage the practice of praying corporately; Paul tells Timothy that he wants 'the men everywhere to pray, lifting up holy hands without anger or disputing' (1 Timothy 2:8). The early Church were also clearly committed to corporate prayer as part of their regular practice; Luke tells us that, 'they devoted themselves to the apostles' teaching and the fellowship, to the breaking of bread and the prayers' (Acts 2:42). It is important to note that whilst we attempt to speak of the value of corporate prayer, we do not claim that corporate prayer is more valuable than private prayer, but rather, that corporate prayer and private prayer are importantly different in the values they offer.

Let us begin by considering the general question of what value corporate prayer might have by considering the following description of prayer in the Quaker community:

[a] In the quiet we look for a sense of connection. This might be a connection with those around us, with our deepest selves, or perhaps with God. As we feel this sense of encounter grow stronger, we may begin to see the world and our relationships in a new way. Our worship may take us beyond our own thoughts and ideas to help us respond more creatively to the world around us... Anyone can contribute to a Quaker meeting for worship - there is no leader. We do have people with a responsibility to encourage and nurture ministry, but we don't believe that makes them more important. We call these people 'elders'...You can sit anywhere you want. No seats are special or reserved. Chairs or benches are usually arranged in a circle or a square. This helps us connect with each another and reminds us that we are worshipping as equals. The meeting starts as soon as the first person enters the room. (Quakers In Britain, n.d.) ${ }^{8}$

Here, prayer is described not only as having value in communicating with God, but also as having value for strengthening our relationships with other people. This value does not seem to be unique to the Quaker tradition either. Whilst the details of specific practices in various Christian traditions might be different, a generalised point can be drawn: one of the differences between corporate and private prayer is that corporate prayer allows us to engage with other people, as well as with God.

This difference in the nature of corporate prayer might also point us to some of its potential benefits - in the example above, the writer speaks of the sense of connection which is available from engaging in group prayer, which is surely lacking from private prayer. Another answer which has been given to the question of the value of corporate prayer is that in certain respects, corporate prayer has the potential to be more effective than private prayer. Note, this is not to say that corporate prayer is more valuable than private prayer; indeed, there are surely values to private prayer which are entirely lacking from corporate prayer (e.g. the opportunity for intimate I-thou communication with God might be less available in some corporate contexts).

Let us consider this claim that corporate prayer has the potential to be more effective because of its communal dimension in more detail.

First, the $20^{\text {th }}$ century Presbyterian minister and theologian H. H. Farmer claims that corporate prayer has the potential to be effective in ways that individual prayer often cannot in his discussion of divine personhood in The World and God. Farmer entered academic theology after a long period of time in ministry, and this is reflected in his writings in the emphasis on the practical outworkings of various theological positions. The Word and God is not primarily a book addressing issues of prayer, but rather, a theological exploration of what it means to describe God as personal, and an application of this theology to issues of practice, such as prayer. The primary discussion of prayer in the text focuses not on corporate prayer, but rather, on prayer as 
a means of responding to the person of God. Many of the examples given by Farmer are taken from instances of private prayer.

Later in the text, in a chapter on divine providence, Farmer considers the relationship between God's providence and the practice of prayer. He writes that, 'reconciled man...becomes a co-operator with God, so that through him God gets a purchase on the human scene not otherwise possible. The new life of co-operation with God is manifested in prayer, and in a daily activity increasingly informed and guided by the divine Spirit' $(1942,261)$. As with the earlier discussion of prayer in the text, here Farmer affirms that prayer predominantly involves the individual's 'awareness' of 'having being sought and found and reconciled by...[the] love of God' $(1942,262)$. Yet, within this discussion, Farmer stresses that there are implications for thinking of prayer as a co-operation with the will of God. For instance, he notes, thinking of prayer as cooperative means that mere repetition of some set of words is not sufficient for prayer to be effective, we must also enter into the situation of those we pray for in 'a deliberate act to enter into' the needs of others $(1942,263)$. In this context, Farmer also stresses that one implication of thinking of prayer as a co-operation with the will of God is that we can see a particular value in praying corporately. He writes that, seeing prayer as a co-operative venture with God

indicates the value of corporate prayer, on which the Christian consciousness has always insisted. If there is an added effectiveness in prayers which, without ceasing to be the expression of the individual's own heart, are also corporate, it is because such prayers are prayers of fellowship, prayers of the Church. They rest on, and carry the power of, at least a partial realisation of that to which all true prayer is directed, namely that membership one of another in the love of God, which is the kingdom. To regard corporate prayer as though it were an addition sum, so that the more people there are praying for anything the more certain is the result, merely because there are, so to say, more units of prayer-pressure per square-inch being exercised, is, of course, shallow and absurd. More people at prayer means more effectiveness in prayer only if it represents an extension and a deepening of fellowship, a passing of more personalities out of the lower and sinful status of isolation into the higher and redeemed status of loving co-operation in God for the high ends of His kingdom. (264-265)

Thus, Farmer claims, if we think of prayer as a means of co-operating with God's will, then one implication is that we should recognise corporate prayer as having a certain kind of efficiency. Again, this claim need not diminish the value of private prayer (this would be strange considering Farmer spends much longer discussing the value of prayer in non-corporate contexts), but rather, it stresses the difference between the two kinds of prayer and the potential value which might arise because of their difference in nature.

Secondly, the South African philosopher and theologian Vincent Brümmer, in his influential work on the philosophy of prayer, claims that, 'corporate prayer is more effective than individual prayer, not because it brings more pressure to bear on God but because it enlists more people in the realization of God's will' $(1984,58)$. Let us quickly contextualise this discussion. Brümmer is directly building on Farmer's remarks here, but the context of his discussions is much narrower than Farmer's. Brümmer is primarily concerned with the philosophical question (sometimes dubbed 'the problem of petitionary prayer') of why a perfectly good God would listen and respond to the petitions of finite imperfect creatures. These remarks on the efficacy of corporate petitionary prayer conclude his discussion of petitionary intercessory prayer. As he describes his position, intercessory prayer 'is a prayer in which the person who prays both asks God to act on behalf of the person or cause for whom he intercedes, and also makes himself available as a secondary cause through whom God could act in answering prayer' $(1984,57)$. In other words, on Brümmer's view, one of the reasons that God asks us to petition him in interceding for others is so that we might co-operate with God's will more fully. One implication 
of this view Brümmer claims, is that corporate prayer is more effective, since it allows more people to be enlisted into the realization of God's will.

Thus, as we see in both Farmer's and Brümmer's works, the claim that corporate prayer is more effective in certain contexts is the implication of a certain co-operative view of petitionary prayer. We are not concerned here with defending this view of petitionary or intercessory prayer, but rather, in this paper, we aim to explore why it might be that corporate prayer sometimes has potential to be more effective in the ways Farmer and Brümmer envision. If their views of intercessory prayer turn out to be wrong, we hope to still have shown that there is some truth in their claim that corporate prayer has potential to be more effective. Before exploring this claim in more detail, however, some clarifications are in order. To many people, the claim the corporate prayer has potential to be more efficient than private prayer will seem contentious, if not obviously false. For as we have already acknowledged, there are many instances in Scripture in which private prayer is both modelled and exhorted. We need to be careful to examine just what this claim concerning corporate prayer's efficiency amounts to, then.

First, the claim that corporate prayer has potential to be more effective is not equivalent to saying that corporate prayer is more valuable. For this would assume that the only aim of prayer is efficiency of ends-indeed, it seems obvious (to the authors at least) that private prayer serves much better as a means of developing personal closeness in relationship with God. Another way of putting this same point is to note that different forms or contexts of prayer are equally effective but for different kinds of outcomes (such as differential effects on mental or spiritual health), this is a point explored in research by Baesler and Ladd (2009). ${ }^{9}$ Moreover, as is evident in both Brümmer's and Farmer's works, claims about a specific value of corporate prayer do not amount to a pitting of corporate prayer against private prayer. Indeed, both Brümmer and Farmer spend considerably more time exploring private prayer than corporate prayer in the works which these above claims are made. Thus, it is important to note that a claim about differences in value does not amount to any kind of claim concerning the preference or hierarchy of such value.

Secondly, the claim is not that corporate prayer is always more efficient. As an anonymous referee helpfully points out to us, this stronger claim is clearly false for it would imply that Jesus's praying in Gethsemane would have been improved by waking up the disciples (Matthew 6:6-14). It is important to see that there are many cases in which corporate prayer is less effective than private prayer-if one is praying in a context which distracts one from God, or which distorts the message of Scripture, then praying with others might have negative consequences, rather than positive. The claim made by Brümmer and Farmer (at least as we interpret it) is that corporate prayer has the potential to be more effective than private prayer because it allows us to influence one another (as well as God). As Farmer puts it, corporate prayer is more effective, 'only if it represents an extension out of the lower and sinful status of isolation into the higher and redeemed status of loving co-operation in God for the high ends of his kingdom' (1939, 265; emphasis added). In other words, since corporate prayer allows us to influence one another in certain respects (and it is these certain respects we attempt to flesh out in this paper), it allows us to influence one another positively only if this influence is directed toward the ends of God's will and God's kingdom.

With these clarifications in place, we can see that the claim concerning efficiency is not a claim about corporate prayer being better or more important than private prayer, nor is it a claim which applies to all instances of corporate prayer. But rather, the claim is the relatively weak claim that since corporate prayer allows us to influence one another, it has the potential to be more effective in actualising certain ends. The question we aim to explore is just what the nature of this influence is and just why it might allow some kinds of prayer to be more effective. As Bernard Spilka and Kevin Ladd (2012) note in their comprehensive overview of the psychology of prayer, in praying in a group situation, 'the prayer is typically conceived as an occasion when one is connected not only with a singular object (i.e., one’s Deity) but also is simultaneously in 
the presence of other believers' $(2012,44)$. As they go on to describe, this sense of connection with other believers, can create social bonds, as well as influencing and enhancing individuals' own experiences of prayer' $(2012,44)$. It is this sense of connection as a means of influence that we explore in more detail in the remainder of this paper. Whilst some of our discussion overlaps with Spilka and Ladd's, we develop this discussion in a much more specific way, as their study attempts to give a comprehensive overview of the psychology of prayer and not just corporate prayer.

To do this, we begin by considering what it is for prayer to be shared by drawing on the psychological literature on joint attention and common knowledge. We then suggest that this analysis of praying together can help us to give an account of prayer's value and effectiveness. Thus, the value of corporate prayers appears to be found in its ability to influence pray-ers to think and act differently, and ideally, to influence one another to bring about Godly ends. In what follows, we offer an account of corporate prayer that seeks to address why praying together has this value. Note, as will become clear later in the paper, it is sometimes hard to distinguish between private and corporate prayer, especially if we emphasise the importance of prayer as contributing to the larger metaphysical unity of the whole Church. On the picture we go on to develop, one of the key differences between these two kinds of prayer is phenomenological.

\subsection{Physical Co-Presence, Praying Together and Sharing Attention}

What does it mean to pray together? First, as we have highlighted above, whilst most traditions use some kind of corporate prayer, this does not always take the same format. Thus, it will be helpful to consider some examples of how corporate prayer is practiced by means of three examples. We deliberately begin by considering cases in which prayer involves physical copresence between participants, and later turn to consider cases in which there is little or no physical co-presence. The first is a description of corporate prayer at a Vineyard congregation in the USA, the second is taken from a Franciscan order in the United Kingdom, and the third is an account of a kind of prayer practiced in some Korean churches:

[b] People pray for each other in many different ways. In 'prayer ministry,' the person for whom one is praying is physically present. One stands before the person and puts one's hand on their arm or shoulder, or - if praying in a large group-on the arm or shoulder of someone who is touching them, or at least with one one's hands out facing them. (Luhrmann, 2012, 49)

[c] The chapel was laid out with pews facing each other. The brothers would meet to pray three times a day. Facing one another, they would recite lines of the liturgy together, each side of the room taking it in turns to recite each line of a psalm or prayer. Almost instinctively, all of the participants (other than me) knew where to pause and when to switch sides. (Author's own account)

[d] 'A unique and special Korean prayer style is called Tongsung Kido. Tongsung means, 'cry out together loudly,' and Kido means, 'pray.'... during worship, usually at the time of special prayer request, the minister or the worship leader will call the congregation to pray in unison. The whole congregation joins together to pray aloud, individually at the same time. Sometimes, in the beginning of prayer, the congregation may shout, 'Lord! Lord! Lord!' in unison, as a cooperative sign of engaging in prayer. Usually the congregation is given a specific amount of time to pray, with a common theme of petition. At the end of the time allotted, the minister's closing prayer finishes.' (Chun, 2017) 
What is it about these experiences that make them all instances of corporate prayer? A simple, intuitive response might be that these varied examples (along with many other examples of corporate prayer) are cases in which the situation of praying is in some way shared. That is, individuals come together to pray in the same space and at the same time. However, whilst this response might appear intuitive, there are some obvious counter-examples. For instance, it seems entirely possible to be praying in the same space and at the same time as another person, yet not be engaged in corporate prayer. It might be, for instance, that John and Mary just happen to be in the same church building, praying at the same time, but neither of them realises the other is also present. In such a case, despite John and Mary praying in the same space at the same time, it would seem strange to describe this as an instance of corporate prayer. What is lacking from this situation, we think, is the sense of sharedness that accompanies the examples of prayer in examples [a]-[d].

The sense of sharedness that underlies corporate prayer is something that is by no means unique to religious rituals and practices; humans are an immensely social species, and our experience of the world involves many varied shared experiences. We watch football matches together, we go to parties together, we sit on public transport together. Moreover, sharing these experiences plays an important role in how we relate to one another- our relationships depend on, and are deepened by, the extent of our shared experience with one another. Corporate religious practices are one such instance of shared experience. They can therefore be understood, to some extent, by considering the cognitive mechanisms that underpin such shared experiences.

An influential hypothesis advanced by Michael Tomasello and his colleagues is that this capacity for shared experience stems from what he and others have termed shared intentionality (Tomasello, Carpenter, Call, Behne and Moll, 2005). Shared intentionality refers to the ability and motivation to engage in cooperative activities that involve the sharing of intentions and goals (as well as other psychological states such as shared emotions and shared beliefs) — to act as a 'We'. Typically, examples that are given of shared intentionality refer to two or more individuals coordinating in some task such as performing a dance routine (Searle, 1992) or playing a musical duet together (Searle, 2010). These cases all involve individuals acting not merely as individuals, but also intending that their actions form part of a wider 'We'. Whilst how we should analyse the nature of these we-intentions is hotly contested, ${ }^{10}$ there is widespread agreement in the philosophical literature that there is some difference between individual and collectively intended action.

It has been observed that our first shared experiences of the world and the earliest expression of shared intentionality are found in the primordial sharing situation of joint attention. We here follow others (Tomasello, 2014; Zahavi and Satne, 2015) in claiming that shared intentionality takes different forms, from dyadic engagements with a particular other to 'forms that go beyond the here and now and involve the construction of a common cultural ground (involving conventions, norms and institutions)' (Zahavi and Satne, 2015, 2). Under a broad definition, joint attention describes a situation in which two or more individuals attend to something together. This 'something' can be a variety of types of target: a physical object, event or abstract symbol. A textbook example would be the situation in which an infant playing with a toy looks up to his mother, smiles, and holds the toy up to her, thereby 'triangulating' their attention onto the toy. Although gaze is the typical modality that is considered in investigations of joint attention, it can be coordinated through other modalities such as touch and speech. ${ }^{11}$

Thus, at least part of what it is for an experience to be shared is that the individuals involved are engaged in jointly attending to some object or event. Whilst perspectives differ on how to understand this sharedness (see, for example, Tomasello, 1995 versus Hobson, 2005; Reddy, 2008), there is a widespread agreement that some stipulation about mutual awareness is important for joint attention to be considered truly joint or shared (Carpenter and Liebal, 2011; Eilan, ms.; Hobson, 2005; Tomasello, 1995). It is important to note that simply orienting to a common focus is not joint attention in a strict sense; there is no mutuality to the experience 
(Tomasello, 1995). Consider, for example, the situation in which a train station full of passengers attend to the screen displaying information about train times. Even though the passengers attend to the same target, it seems intuitive to say that this experience is not shared in a strong sense. Even in cases where an attender causes another to attend to a common target (e.g., in following another's gaze to a target), there might still be a critical absence of interpersonal connectedness that provides the crucial ingredient of sharedness.

So, to give an account of sharedness, more detail is needed than simply noting the importance of simultaneous object attention. To fill this account out in more detail then, following a number of researchers, ${ }^{12}$ we suggest that joint attention should be understood through the lens of the 'second-person perspective'. This line of argument is not to deny the importance of third-person modes of social cognition in how we understand others' minds. Rather, it emphasises that shared experiences have their basis in interactive, reciprocal engagements. Broadly conceived, the second-person perspective highlights that human social understanding is different in important ways when others are engaged directly and interactively as a 'You' (second-personally) as opposed to viewing them as a 'He', 'She' or 'It' ( ${ }^{\text {rd }}$ personally). Suppose John and Mary are reading in a library at the same time for some time, and then become aware of one another by, say, sharing a knowing look concerning a disturbance from a group of noisy students. The knowing look provides an interactive, communicative connection that makes the experience of the noisy students shared between John and Mary. ${ }^{13}$ Prior to the knowing look, we would say that the experience of the students was common between John and Mary but is only shared once the second-person connection is established. ${ }^{14}$ Interactive engagements are inherently other-involving and reciprocal in a way that is not possible from simply observing another's behaviour. ${ }^{15}$ John might intently study Mary's behaviour and carefully consider her perspective, but no amount of individual thinking can make an experience truly mutual or shared; Mary must be both aware of John's attention towards her and must indicate her attention to John for true mutuality to be present. In other words, there must be a sense of 'bi-directionality' (Zahavi, 2015). In second-person interactions, both participants contribute to the structure of the interaction; timing and responsivity become key (Moore and Barresi, 2017). Participants in an embodied joint attention interaction (embodied here meaning with a co-present, engaged other) align their bodily movements and attentional states. ${ }^{16}$

The above considerations concerning joint attention and the second-person perspective have potential to explain what makes certain instances of prayer corporate, or shared, we think. For in the example above, one of the crucial things that was lacking in John and Mary's experiences was that they were not engaged in joint attention. In a recent article, Joshua Cockayne and David Efird (2018) have suggested that corporate liturgy might provide an opportunity for participants of a liturgy to engage in joint attention with one another whilst mutually attending to the words of the liturgy, and subsequently to God's presence as a mutual object of their perception. ${ }^{17}$ Building on much of the literature cited above, they claim that jointly attending to a liturgical script can allow congregants to shape and direct one another's experience of God. They suggest that an awareness of other worshippers might allow us 'to redirect our own attention and thereby to experience some different aspect of God, thereby removing our biases in important ways.' $(2018,320)$. Thus, perhaps the same can be said about the sharedness of corporate prayer. Just as the liturgical script can provide a mutual object around which the congregation can focus and guide one another's attention, the practice of corporate prayer might allow for a kind of mutual-object focusing. In example [b], this seems to be precisely what occurs - the words of the intercessor provide an object of attention, which the congregation can jointly attend to, thereby shaping their own perception of the environment and, perhaps, their experience of God.

However, whilst an appeal to the psychology of interactive engagement has some application, it also has its limits, at least in the case of corporate prayer. Given the critical nature of second-person engagement for the jointness of joint attention, potential problems arise when 
considering typical cases of corporate prayer. In most church services, we see only the backs of people's heads, or the top of our own shoes. In instances of corporate prayer, most of the congregation close their eyes and are perhaps only directly aware of the individual they can audibly hear. In the case of Tanya Luhrmann's visit to the Vineyard church, this might be the individual whose hand was on her. But in many contexts the only person we might be directly aware of is the leader of the intercessory prayers. Cases can also vary in how shared the experience is. In cases of 'Tongsung Kido', the act is necessarily shared yet also highly individualistic, in the sense that the content of each prayer is known only to the individual prayer. Whilst this is clearly not the case for all instances of corporate prayer, it might appear that appealing to an account of joint attention to explain the sharedness of a situation is problematic, at least for some instances of corporate prayer. Moreover, as we will suggest, some cases of shared prayer are even more difficult to account for by appealing to embodied, interactive joint attention. The case of the National Day of Prayer appears to be one such case in which the sense of sharedness extends beyond those who were engaged in interactive joint attention.

In the next section, we suggest that a broader concept of second-personal engagement can help us to provide an account of the sharedness of corporate prayer that does not require participants to be interactively sharing attention with each other throughout. We suggest that by drawing together recent psychological and philosophical literature that emphasises the importance of connecting shared 'We' experiences with the experience of intersubjective secondperson engagement and joint attention (Brinck, Zahavi and Reddy, 2017), we can provide a broader account of the shared nature of corporate prayer.

\subsection{Shared Situations and Groups: Moving Beyond Physical Co-Presence}

So far, we have described the importance of joint attention in understanding shared experience, and its necessarily interactive, engaged character. We have also suggested that understanding corporate prayer in terms of joint attention provides a helpful starting point for understanding the sharedness of corporate prayer. This analysis fits cleanly within small-scale cases of praying together, where participants can interactively respond to each other's prayers. But humans are capable of collective intentional acts that go beyond the here-and-now and create richly complex cultural activities and institutions. ${ }^{18}$ In this section, we consider how broader metaphysical claims about the nature of praying as part of a larger community can have epistemological implications for what gives certain kinds of the prayer the phenomenology of sharedness.

Focusing only on examples of prayer which involve physical co-presence threatens to miss important points raised in the literature about joint attention in large groups ${ }^{19}$ as well as evidence of the influences of group rituals as providing affiliative benefits ${ }^{20}$ and forms of common knowledge amongst the participators in those activities. ${ }^{21}$ Examples such as the following force us to think more broadly about the notion of sharedness in corporate prayer:

[e] The Church had been running a 40-day community prayer event over lent, with materials for the congregation to take home, giving them short passages with brief prayers to use during private devotion. One woman in the community was particularly thankful for the event, as she was unable to regularly attend Sunday worship due to working away from the area. She described the comfort that came from praying with an awareness that others were praying alongside her. (Author's own experience of community prayer at a Baptist Church)

The challenge that cases such as this raise is to broaden our understanding of what it means to share attention beyond the kind of attention sharing that occurs in an embodied, second-person dyadic interaction. Whilst it is beyond the scope of this paper to provide a full account of sharing attention as a group, we will provide a general framework for understanding this issue that can help explain cases of corporate prayer that extend more broadly than embodied second-person 
dyadic interaction. Consider the following three cases to see how such an account might be developed in more general terms:

1. John drives his taxi with Mary riding in the back

2. John and Mary have a conversation while standing in a circle of friends at a cocktail party

3. John and Mary watch the World Cup semi-final together in a large public football match screening

Whilst these cases have important differences, we could describe them all, following Jon Barwise (1989), as 'shared situations'. Barwise uses the term situation as a way of referring to some corner of the world that an individual can access; a shared situation is some corner of the world that two or more individuals share together. Barwise has a technical notion of a situation that is part of his formal semantic theory. We do not intend to commit to the whole of Barwise's project, but, rather, to follow the spirit of his approach; in his words: '.. cognitive activity takes crucial advantage both of the agents' place in the environment and of regularities in their local environment. Moreover, the cognitive abilities of the agent have a certain 'reach' which determines, at any given time, a situation, the largest portion of reality that the agent has access to......this situation may extend quite far in time and space' $(1989,223)$. Our use of the phrase 'shared situation' is with the aim of capturing two key points. First, joint attention occurs in temporally extended episodes or activities (such as in example [e]), and within these activities there is a continual sense of jointness that persists even in the absence of direct second-person engagement. This sense of jointness is weaker than that which emerges from engagement, but is nonetheless important. Second, we use the language of shared situations to emphasise the significance of being embedded in spatial, social and historical settings that shape our cognition, and our social cognition in particular. ${ }^{22}$

What do we mean by 'a continual sense of jointness'? Let us return to cases 1-4 to explore this concept more carefully. In (1), there may be shared moments of joint attention between John and Mary, where they lock on to the same feature of the world (e.g., when Mary points out the right street for John to turn into). But even when they do not (e.g., when Mary is on her phone and John watches the road), there is the sense that there is still something shared about their situation. By participating in the shared activity of the taxi ride, they both inhabit a shared situation, with particular spatial and temporal boundaries; spatially they are constrained by the taxi and its environs, and the temporal limits are set by the length of the shared activity of the taxi ride. They also inhabit a shared culture of norms and information that they can draw upon if need be. This sense of sharedness provides contextual framing by which individuals' actions, communicative or otherwise, can be interpreted.

It is important to note that this embeddedness occurs on multiple scales (Siposova and Carpenter, forthcoming). In (2), whilst there is the situation of the conversation between John and Mary, the situation also involves a wider sense of sharedness in virtue of the circle of friends, which contains the situations involving John and Mary. Each of these layers can be viewed as a shared situation; that is, a context in which there is a sense of common participation and sharedness and which individuals can attend to as it is relevant to them. In case (3), just as in (2) John and Mary's sharedness extends to those who are also gathered at the public screening, but it also seems to extend wider than this- to the other 20 million or so viewers of the televised broadcast of the match, alongside those watching in the stadium. National events such as football matches, royal weddings, and national prayer rallies foster a sense of sharedness that extends much more broadly than those in which one is directly engaged in embodied attention sharing.

A key element of this approach that is important to emphasise is the process of alignment. Participation in a shared situation ensures, to some greater or lesser extent, aligning with the other participants in that situation. Consequently, the 'second-personal' features that 
make an embodied, interactive case of joint attention shared continue to be relevant in the context of a shared situation. Features such as synchrony, contingency and timing continue to be relevant in creating shared experience, as they support the process of alignment that occurs in shared experiences. This has been shown at the level of bodily or 'muscular' coordination (McNeill, 1997), which serves to increase participants' sense of affiliation with each other (we return to this point shortly). But it also occurs at the mental level. For example, simultaneously saying the same words creates the knowledge that these words are a shared target of attention and the subject of our thoughts; therefore, repeating these words establishes these thoughts as more certainly shared (Chwe, 2001). Thus we would argue that shared experiences involve aligning on multiple scales.

The cases above (1-3) have similarities with the examples of corporate prayer: in corporate prayer, like in case (1), there is a sense in which a shared situation exists and pray-ers are praying together, even when little or no direct embodied interaction takes place.

Furthermore, as in (2), in corporate prayer, there are many nested situations - we might only be directly aware of the individual reading the prayers, but there is a sense in which the situation is shared with those one came along to church with, the congregation who are present within the spatial confines of the church, and perhaps even those who are not physically present, but who are praying at home (we consider this case in more detail shortly). By adopting the theoretical notion of shared situations, we have a means of understanding the multi-scaled nature of shared experiences. For example, the case in [d] of Tongsung Kido involves only a minimal level of togetherness (generated by the shared situation of prayer) but is otherwise highly individualistic. In contrast, the liturgical practice shown in [c] strongly emphasises the corporate nature of the activity, both in the practice of responsive reciting of scripture and the physical arrangement of the activity with the brothers facing each other.

\subsection{Shared Situations and the Community of Prayer}

The sense of sharedness that arises from praying as part of a larger church community also appears to have applications when we consider the wider theological picture. As the $20^{\text {th }}$ Century Anglo-Catholic theologian Evelyn Underhill describes in some detail, our private prayer and worship should be seen as united by the work of the Holy Spirit into the larger communion of saints $(1936,80-86)$, whether we are aware of this or not. If this is right, then, metaphysically speaking, prayer is never a 'solitary undertaking' (Underhill, 1936, 81), but rather it always plays a role in the wider community of the Church. There is not space here to unpick the metaphysical implications of this important theological position, nor to analyse this particular theological claim. However, as we will argue in this section, having the belief that one's prayer plays a role in a wider whole can allow for a phenomenology of sharedness that can exist both in cases of physically co-present prayer, but even in cases where one prays alone.

Let us consider two further examples to see how far this account might be extended:

[f] 'Sacred places and churches have an aroma of prayer; it's almost as if the prayers and holiness of countless faithful over generations are clinging to the walls and columns.' (Flanagan, n.d.)

[g] Both on its visible and invisible side... [Christian worship] has a thoroughly social and organic character. The worshipper, however lonely in appearance, comes before God as a member of a great family; part of the Communion of Saints, living and dead. His own small effort of adoration is offered "in and for all". ... he shares the great life and action of the Church... He is immersed in that life, nourished by its traditions, taught, humbled, and upheld by its saints.' (Underhill, 1936, 81) 
Both of these examples invoke some concept of sharedness, despite the fact that there is no direct, embodied second-person engagement between the pray-ers. Whilst there is clearly a metaphysical dimension to this sharedness, we can also think phenomenologically about these cases. In the first case, the pray-er prays together with those who have prayed in the same building in the past (there is a temporal distance). In the second case, the pray-er prays alongside those who are part of the Church as a corporate whole (there is potentially a temporal-spatial distance, along with a dimensional distance; where and when the angels and saints in glory are praying is certainly beyond the scope of this discussion).

Can the shared situation account provide some explanation of what is shared in cases in which there is no direct second-personal engagement? All of the cases involve some kind of phenomenological sharedness - that is, in all three cases the experience that one is not praying alone is taken to play some role in shaping the phenomenology of how one prays. This phenomenology seems to be (at least partially) grounded in the belief that others are praying alongside the individual (Shteynberg, 2015). As we have suggested above, whilst the sharedness of a situation ordinarily involves at least some interactive embodied engagement with others, there appear to be cases (such as the football match in (3), as well as the 1940 National Day of Prayer) in which sharedness is grounded purely in a belief about others, rather than in direct engagement with them.

It is important to clarify this point further. We have so far considered various conceptual components of sharing attention. One is that it requires the motivation to share experiences and attention with others (Tomasello et al, 2005). Another is that it is, in many cases, an activity or action (Kidwell \& Zimmermann, 2007), something that is enacted with others in embodied, second personal interactions. The third, and most pertinent here, is that it involves the joint attention state, in which one believes oneself to be sharing an experience with others (Shteynberg, 2015). Early in development, this arises primarily (arguably, exclusively) through second personal engagement. But adults simply need the appropriate beliefs to achieve this state. For example, Risko and Kingstone (2011) found that participants (being watched by a hidden camera) avoided looking at potentially embarrassing stimulus (a swimsuit calendar on the wall) when they believed what they saw was in joint attention (wearing a functioning eye-tracking headset versus wearing a broken headset). It is reasonable therefore to claim that for a phenomenological experience of sharedness, holding certain beliefs suffices.

This seems to account for what it is that makes examples $[\mathrm{e}],[\mathrm{f}]$ and $[\mathrm{g}]$ instances of corporate prayer. These beliefs can be generated, as in [f], by entering environments which have a particular significance to individuals or communities. It would seem reasonable to argue that the spatial setting is important for facilitating a sense of sharedness. Consider, for example, how the physical layout of a stadium emphasises a sense that the game of football being played is the common focus of attention. Similarly, reflecting on the theological truth that our prayers are part of a wider corporate body, as in $[\mathrm{g}]$, may achieve a phenomenological sense of sharednessIn summary, it is clear that the boundaries of what constitutes a shared situation are fairly blurry and there appears to be a scale which ranges from embodied, interactive joint attention experiences of prayer (such as cases [b], [c], and [d]), to cases in which there is some embodied, dyadic joint attention, but the sense of sharedness extends beyond the experience (such as in [e]) and to then cases which appear have no embodied, dyadic joint attention but which appear to still have a phenomenology of sharedness (such as [f] and $[\mathrm{g}]$ ). Along this scale, the secondperson, interactive features, which generate closer forms of alignment, continue to play a role in generating a stronger sense of sharedness, whether that be through the synchronous movement of the crowd or the simultaneous speech of the congregation reading liturgy. So, while the joint attention state can come about via relevant contextual cues that trigger the appropriate beliefs, second-personal features continue to play a role in all varieties of shared experience. 


\section{The Value of Corporate Prayer as a Shared Situation}

Let us return to our initial question about the potential value of corporate prayer, and the ways in which it is distinct from private prayer. As we outlined in the opening section, one potential value of corporate prayer is its ability to engage us not only with God, but also with one another. This value, as Brümmer and Farmer have described it, is that corporate prayer allows us to be influenced by one another so that we might enlist one another into enacting God's will in ways that private prayer often cannot. We are now in a clearer position to give a possible explanation for why this kind of influence occurs.

As we have suggested in the previous two sections, corporate prayer is an instance of a shared situation in which a sense of sharedness can be established by means of embodied, dyadic joint attention experiences, as well as by certain environments or scenarios that prompt us to form relevant beliefs relating to the sharedness of our situation. This can help us to think more carefully about the value of prayer as a shared situation.

Thinking of corporate prayer as an instance of a shared situation can help us to see how pray-ers might influence one another in the way described. For instance, one way of capturing the increase of effectiveness in certain kinds of prayer is in terms of what philosophers have called 'common knowledge' (Lewis, 1969). That is, there is a certain kind of knowledge that occurs in shared situations in which an individual knows not only some fact, but also that each other person with whom the situation is shared knows the fact, and that they each know that each other person knows that they know. As Michael Chwe (2001) describes it, common knowledge that occurs in shared situations allows us to get over so-called 'coordination problems', in which:

...each person wants to participate in a joint action only if others participate also. One way to coordinate is simply to communicate a message, such as 'Let's all participate.' But because each person will participate only if others do, for the message to be successful, each person must not only know about it, each person must know that each other person knows about it. $(2001,8)$

Chwe thinks that common knowledge allows us to overcome coordination problems in a variety of shared situations. For instance, suppose a group are holidaying together and get separated in a busy street. Because each member of the group knows that the Ice Cream parlour is the agreed rendezvous point, as well as knowing that each of the other members knows this and that each member knows that each other member knows, the group are able to find one another when separated and thereby to overcome coordination problems. This kind of coordination can also occur in wider-scale groups, as Chwe points out. For example, Chwe notes, when the Apple Macintosh Computer was first introduced to the market, its products were incompatible with other computer devices and would only be able to share their data with fellow Macintosh users. This posed a kind of coordination problem - 'a potential buyer would be more likely to buy if others bought them also' $(2001,11)$. Apple overcame this coordination problem by presenting a short, stimulating commercial and screened it during the Super Bowl, one of the most watched television events of the year, thereby creating a kind of common knowledge about the Macintosh.

Chwe's discussion of common knowledge points to a helpful way of thinking about corporate prayer as a shared situation-certain goals or aims can become common knowledge between participants in a way that would be impossible with private prayer. As one referee helpfully highlights, this is pertinent to cases of what we could call 'holy gossip'; prayers that make certain facts common knowledge which would otherwise be socially unacceptable to mention, such as 'God please help David with his gambling problem'. Such examples highlight how prayer provides a unique context in which to share common knowledge within a community. They also bring out the complexity of the interaction between context and content; 
such a prayer would carry a different significance if said between a married couple as opposed to in a church-wide prayer meeting. For our account, we would claim that the advantage of the shared situation approach is that it emphasises how the situation provides contextual framing which shapes the significance of what is prayed to those praying. This provides one motivating factor for engaging in activities that would otherwise be overly risky, whether that is purchasing a new computer that is incompatible with other brands (which was true of the Macintosh), or launching out to sea in a sailing boat to rescue stranded soldiers. Indeed, this seems to capture what goes on in many cases of prayer in which corporate prayer is supposedly more effective in enlisting others in the will of God. A part of what happens when individuals join together with a sense of sharedness is that some ideal becomes common knowledge between them, or at least that this common knowledge gets reinforced, making it more salient in their memories. ${ }^{23}$ Thus, as in example [e], when the congregant was spurred on to pray more fervently because she knew her community was praying alongside her, the sharedness of the situation no doubt proved invaluable in creating this common knowledge. Moreover, it seems plausible that this sense of sharedness plays an important role in overcoming coordination problems in religious communities more generally - the knowledge that I am not the only person who is aware of the needs in the community, or the world, surely plays an important role in overcoming the feeling that 'I am just one person who cannot change the world'. What the sharedness of corporate prayer reiterates is that the values of a particular religious tradition, as well as certain duties or obligations, are common knowledge, thereby undermining the feeling of inadequacy against the daunting task of transforming the world. Psychological research has found that shared attention to a goal increases individuals' motivation to complete that task, even with unseen others (Shteynberg and Galinsky, 2011; Walton, Cohen, Cwir and Spencer, 2012).

The above observation seems to be true of cases which include embodied dyadic joint attention (such as [b], [c], and [d]) but also of cases in which all that exists is a belief in some kind of sharedness (such as $[\mathrm{f}]$ and $[\mathrm{g}]$ ) which results from a particular environment or state of mind. The idea that one is not alone in, say, building the kingdom of God, or caring for the poor, or preaching the gospel, allows prayer to be more effective in overcoming problems of coordination. It also seems important that this kind of sharedness can be felt with those members of the Church who are temporally or spatially distant, or at the very least that the prayer may feel reassured that her labour is not in vain (1 Corinthians 15:58). As a referee points out to us - there are also many examples of prayer in Scripture in which corporate prayer is described as ineffective because God does not attend to their prayers. See Isaiah 1:15, for instance (note that the second person pronoun is plural):

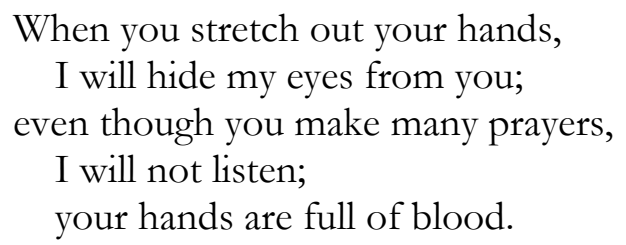

It is important to reiterate again that our claim is not that corporate prayer is always more effective, but that it has potential to be more effective. And so such examples are not counterexamples to our argument, but rather, examples in which corporate prayer does not fulfil its potential. Indeed, since, as we have seen, group activities such as prayer provide opportunity to influence one another; one way corporate prayer might fail to fulfil its potential is in allowing us to exert the wrong kind of influence over one another. Yet, by appealing to an account of common knowledge, we have seen one way in which corporate prayer can be more effective in enlisting a group of individuals to enact the will of God; namely, by allowing them to overcome the coordination problems which come from the belief that one person can act effectively. 
Another explanation for why praying together in a shared situation can be more effective than praying in private is that it allows for increased affiliation. In his book on coordinated movement, William McNeill describes how certain rituals such as dancing and military marching provide a kind of unity of feeling and consciousness between participants (1997, 7). Writing about the example of group dancing, McNeill describes a kind of 'boundary loss' occurring in which the individual feels they are one with the group because of a 'blurring of self-awareness and the heightening of fellow-feeling with all who share in the dance' $(1997,8) .{ }^{24}$ He argues that a similar phenomenon can be found in the use of military drills-acting together in unison with others can 'create and sustain group cohesion; and the creation and maintenance of social groups' $(1997,10)$. McNeill claims that acting together in dance and ritual fosters this sense of group cohesion, thereby achieving a kind of 'practical efficiency' $(1997,66)$ regarding the group's aims and causes.

Numerous studies in social psychology have vindicated McNeill's arguments, showing that synchronous muscular coordination produces affiliation in both pairs and groups ${ }^{25}$. Similarly important is the role on imitation and mimicry. Following others such as Chartrand and van Baaren (2009), we use imitation to refer to intentional acts of imitating and mimicry to refer to spontaneous and non-conscious forms of imitation. Both forms have related but distinct effects. Research on imitation and mimicry has considered its role in understanding others as 'like me' (Meltzoff, 2005); both as thinking agents experiencing the world in a similar way and as those with whom I am (or can be) affiliated (Užgiris, 1981). ${ }^{26}$ Given the critical role of imitation in the development of understanding other minds and identifying with others, it is plausible that largescale activities involving imitation and mimicry support the process of aligning with others, increasing relational closeness and shared attitudes (Chartrand and van Baaren, 2009). Corporate prayer, which frequently involves both intentionally imitating a leader's or each others' actions and words is therefore a context that is ideal for increasing affiliation between the community of pray-ers.

Whilst not all corporate prayer includes muscular bonding and the kind of physicality of acting together which dance and military drill allow for (McNeill does discuss some instances of prayer that do in chapter 4), the sense of togetherness that shared situations can foster seems more generally applicable. Evidence from social psychology suggests that it is not just muscular coordination that can produce affiliation, but also sharing experiences in general. Research in social psychology has shown that sharing an experience boosts the emotional valence of that experience. Boothby and colleagues have demonstrated that sharing the experience of eating caused participants to enjoy the experience of eating chocolate more than eating it alone (Boothby, Clark and Bargh, 2014). This was felt even more strongly by friends who completed the task (Boothby, Smith, Clark and Bargh, 2016). Such effects are also found in cases of negatively valenced shared experiences. Bastian and colleagues (2014) found that strangers who experienced pain together felt closer than controls who experienced a non-painful shared experience, and were more cooperative when later asked to take part in an economic game.

These findings suggest that sharing the experience of corporate prayer may both be an intrinsically unifying activity, but also something that increases the strength of emotions towards the target of attention (which may be a theological truth or a practical problem that needs to be overcome), thereby increasing the strength of shared belief and likelihood of action. This line of thinking fits with anthropological research on ritual, which has long emphasised the role of ritual in fostering close social bonds between participants. In recent years there has been an increased interest in the psychological effects of ritual (Fischer, Callander, Reddish \& Bulbulbia, 2013; Norton and Gino, 2014; Wen, Herrman and Legare, 2016), and some attempts to integrate insight from anthropology with those from evolutionary psychology (e.g., Watson-Jones \& Legare, 2016). However, we would want to exercise caution and avoid treating 'ritual' as a monolithic entity; cases of corporate prayer will have their own unique features and effects (and corporate prayer refers to a heterogeneous collection of practices). 
As we have seen, one supposed value of corporate prayer is its ability to enlist more people around a certain goal or ideal and to make this goal common knowledge within a community. It appears that one further corollary of this phenomenon is that group ritual builds a sense of community in which the individual identifies as part of a group and feels more closely connected to those in the group. In the Christian tradition, emphasis is put on the fact that the togetherness of God's people can be enlisted into the will of God, to bring about good. One benefit of praying together regularly is that this togetherness is emphasised, and the sense of sharedness is increased. Thus, we can see one further way in which corporate prayer might have potential to be more effective than private prayer in virtue of its shared nature.

\section{Conclusion}

We have been considering the nature and value of corporate prayer. As we have seen, whilst some theologians are keen to stress that corporate prayer and private prayer are importantly different, it is not always clear what this difference amounts to. We have offered an analysis of corporate prayer as a kind of shared situation. As we have suggested, this feeling of sharedness has a scale of intensity and can be caused in a variety of ways. Typically, embodied, interactive joint attention plays an important role in creating and maintaining shared situations, even if the sense of sharedness is temporally extended beyond the moments of interactive engagement. However, we have suggested that there might be other means of creating and maintaining the sense of sharedness that is vital to corporate prayer, by means of certain environmental or epistemic stimuli such as praying in a sacred space or with an awareness that the whole Church is joined together in prayer. Moreover, we have given two possible explanations for why corporate prayer might be more effective than private prayer in certain respects. First, because corporate prayer creates a shared situation, it also allows for a kind of common knowledge, thereby overcoming coordination problems and defeating the belief that 'one person cannot change the world'. Second, because corporate prayer involves aligning with others on multiple scales, it fosters and encourages a sense of togetherness within a community which can thereby spur individuals on to engage in maintaining and pursuing certain ideals and goals.

Finally, it is important to reflect on the limitations of what we have argued here. Throughout, we have not sought to give a full theological explanation of what corporate prayer does or aims to do, nor is our purpose to give a reductive explanation of how prayers are answered which excludes the need for theological explanations. Indeed, given that the New Testament seeks to emphasise that prayer involves the intercessions of the Holy Spirit (Romans 8:26), alongside the prayers of the people of the Church, it is important to note that focusing only on the ways in which human pray-ers influence one another cannot fully account for what is going on in corporate prayer. Nor can it provide a comprehensive account of the value of such prayer. Rather, we have sought to engage in a constructive dialogue between theology, psychology and philosophy in order to enrich our understanding of why corporate prayer can prove to be valuable and effective. There are many more areas that the complementarian approach we have adopted here can help to think further about, which we hope to address at some point in the future. What is the role of the Communion of Saints in corporate prayer? What difference does our metaphysics of the whole Church make to our understanding of the psychology of liturgical practice? What explains the special role of sung prayers in a number of traditions? What role do collective intentions play in liturgical practice? How can a prayerful liturgical community grow together to the extent that even hearing another's footsteps approaching a place of prayer become recognisable and important to the act of praying together? ${ }^{27}$ These are just some of the important theological questions which psychological research can help to explore in the future. 


\section{References}

Akhtar, N. and Gernsbacher, M. A. 2008. 'On privileging the role of gaze in infant social cognition.' Child development perspectives 2(2), 59-65.

Baesler, E.J. 1999. 'A model of interpersonal Christian prayer.' Journal of Communication \& Religion 22(1): 40-64.

Baesler, E.J. and Ladd, K. 2009. 'Exploring prayer contexts and health outcomes: From the chair to the pew.' Journal of Communicaton \& Religion 32(2): 347-374.

Baesler, E.J., Lindvall, T. and Lauricella, S. 2011. 'Assessing Predictions of Relational Prayer Theory: Media and Interpersonal Inputs, Public and Private Prayer Processes, and Spiritual Health.' Southern Communication Journal 76(3): 191-209.

Barwise, John. 1989. The Situation in Logic. Stanford: Centre for the Study of Language and Information.

Bastian, B., Jetten, J. and Ferris, L.J. 2014. 'Pain as social glue: Shared pain increases cooperation.' Psychological science 25(11): 2079-2085.

Benson, H., Dusek, J.A., Sherwood, J.B., Lam, P., Bethea, C.F., Carpenter, W., Levitsky, S., Hill, P.C., Clem, D.W., Jain, M.K. and Drumel, D. 2006. 'Study of the Therapeutic Effects of Intercessory Prayer (STEP) in cardiac bypass patients: a multicenter randomized trial of uncertainty and certainty of receiving intercessory prayer.' American heart journal 151(4): 934-942.

Boothby, E.J., Clark, M.S. and Bargh, J.A. 2014. 'Shared experiences are amplified.' Psychological science 25(12): 2209-2216.

Boothby, E.J., Smith, L.K., Clark, M.S. and Bargh, J.A. 2016. 'Psychological distance moderates the amplification of shared experience.' Personality and Social Psychology Bulletin 42(10): 1431-1444.

Botero, M. 2016. 'Tactless scientists: Ignoring touch in the study of joint attention.' Philosophical Psychology 29(8): 1200-1214.

Bratman, Michael E. 2013. Shared agency: A planning theory of acting together. Oxford University Press.

Brinck, I., Zahavi, D. and Reddy, V. 2017. 'The Primacy of the 'We'?' In C. Durt, T. Fuchs and C. Tewes, Embodiment, Enaction and Culture. MIT Press: 131-147.

Brown, Warren S. and Brad D. Strawn. 2012. The Physcial Nature of Christian Life. Cambridge University Press.

Brümmer, Vincent. 1984. What Are We Doing When We Pray?: A Philosophical Inquiry. London: SCM Press.

Buttelmann, D., Zmyj, N., Daum, M. and Carpenter, M. 2013. 'Selective imitation of in-group over out-group members in 14-month-old infants.' Child Development 84(2): 422-428. 
Campbell, J. 2005. 'Joint attention and common knowledge.' In N. Eilan, C. Hoerl, T.

McCormack, and J. Roessler, Joint attention: Communication and other minds Oxford University Press: 287-297.

Carpenter, Malinda and Liebal, Kristen. 2011. 'Joint attention, communication and knowing together in infancy.' In A. Seemann, Joint attention: New developments in psychology, philosophy of mind and social neuroscience, MIT Press: 159-181.

Chartrand, T.L. and Bargh, J.A. 1999. 'The chameleon effect: the perception-behavior link and social interaction.' Journal of personality and social psychology 76(6): 893-910.

Chartrand, T.L. and van Baaren, R. 2009. 'Human Mimicry.' Advances in Experimental Social Psychology 41: 219-274.

Chwe, Michael Suk-Young. 2001. Rational Ritual: Culture, Coordination, and Common Knowledge.

Chun, Yohang. 2017. 'Tonsung Kido (A Unique Korean Prayer)', The Upper New York Conference News, from: http://www.unyumc.org/news/article/tongsung-kido-a-unique-korean-praver [accessed on 15/08/2018].

Cockayne, Joshua, and David Efird. 2018. 'Common Worship.' Faith and Philosophy vol 35.3: 299325.

Codrons, E., Bernardi, N.F., Vandoni, M. and Bernardi, L. 2014. 'Spontaneous group synchronization of movements and respiratory rhythms.' PLoS One 9(9): e107538.

De Bruin, L., Van Elk, M., and Newen, A. 2012. 'Reconceptualizing second-person interaction.' Frontiers in human neuroscience, 6 (151): 1-10.

Eilan, Naomi. manuscript. 'Joint attention and the second person.' Available at: https://warwick.ac.uk/fac/soc/philosophy/people/eilan/ [accessed on 17/08/2018]

Fabian, Johannes. 2015. Talk about Prayer, An Ethnographic Commentary. Palgrave Macmillan.

Farmer, H. H. 1942. The World and God, New York: Harper

Fischer, R., Callander, R., Reddish, P and Bulbulbia, J. 2013. 'How Do Rituals Affect Cooperation?' Human Nature 24(2) 115-125.

Flanagan, Fr Eamon. N.d. 'Prayer and Sacred Spaces' from: https://www.stpetersphibsboro.ie/prayer-and-sacred-places/ [accessed on 15/08/2018]

Gallagher, Shuan. 2011. 'Interactive coordination in joint attention' In A. Seemann, Joint attention: New developments in psychology, philosophy of mind, and social neuroscience. MIT Press.: 293-305.

Gallotti, Mattia, Fairhurst, Merle T. and Frith, Chris D. 2017 'Alignment in social interactions.' Consciousness and Cognition 48: 253-261.

Giordan, Giuseppe. 2011. 'Toward a Sociology of Prayer' in Giordan G., Swatos, Jr. W. (eds.) Religion, Spiritiuality and Everyday Practice. Springer. 
Giordan, Giuseppe and Woodhead, Linda (eds.). 2015. A Sociology of Prayer. Routledge.

Gómez, J. C. 1996. 'Second person intentional relations and the evolution of social understanding.' Behavioral and Brain Sciences 19(1): 129-130.

Gómez, J. C. 2005. 'Joint attention and the notion of subject: Insights from apes, normal children, and children with autism.' In N. Eilan, C. Hoerl, T. McCormack, and J. Roessler, Joint attention: communication and other minds: Issues in philosophy and psychology, Oxford University Press: 6584.

Gregory, S. E., Jackson, A. and Margaret, C. 2017. 'Joint attention enhances visual working memory.' Journal of Experimental Psychology: Learning, Memory and Cognition 43(2): 237-249.

Hobson, R. Peter. 2005. 'What puts the jointness into joint attention?' In N. Eilan, C. Hoerl, T. McCormack, and J. Roessler, Joint attention: communication and other minds: Issues in philosophy and psychology, Oxford University Press: 185-204.

Hove, M.J. and Risen, J.L., 2009. 'It's all in the timing: Interpersonal synchrony increases affiliation.' Social Cognition 27(6): 949-960.

Howard-Snyder, Daniel, and Frances Howard-Snyder. 2010 'The puzzle of petitionary prayer.' European for the Philosophy of Religion, 2, no. 2: 43-68.

Huebner, Bryce. 2013. 'Socially embedded cognition.' Cognitive systems research 25: 13-18.

Humphrey, C. and Laidlaw, J. 1994. The archetypal actions of ritual: A theory of ritual illustrated by the Jain rite of worship. Oxford University Press, USA.

Jeeves, Malcolm and Ludwig, Thomas. 2018. Psychological Science and Christian Faith: Insights and Enrichments from Constructive Dialogue, Templeton Press.

Kidwell, M. and Zimmerman, D. H. 2007. 'Joint attention as action.' Journal of Pragmatics 39(3): 592-611.

Ladd, Kevin L. and Bernard Spilka. 2014. 'Prayer and health research: proxies, missed targets, and opportunities.' Revista Pistis Praxis 6(1): 33-50.

Lakin, J.L., Jefferis, V.E., Cheng, C.M. and Chartrand, T.L., 2003. 'The chameleon effect as social glue: Evidence for the evolutionary significance of nonconscious mimicry.' Journal of nonverbal behavior 27(3): 145-162.

Liebal, Kristin, Carpenter, Malinda and Tomasello, Michael. 2010. 'Infants' use of shared experience in declarative pointing.' Infancy 15.5: 545-556.

Luhrmann, Tanya M. 2012. When God talks back: Understanding the American evangelical relationship with God. Vintage.

McNeill, William H. 1997. Keeping together in time. Harvard University Press.

Meltzoff, A.N., 2005. 'Imitation and other minds: The "like me" hypothesis.' Perspectives on imitation: From neuroscience to social science 2: 55-77. 
Moore, C. and Barresi, J. 2017. 'The role of second-person information in the development of social understanding.' Frontiers in Psychology 8: 1-15.

Moore, C., and Dunham, P. 1995. Joint attention: Its origins and role in development. Hillsdale:

Lawrence Erlbaum Associates.

Myers, D.G. 1999. 'Is prayer clinically effective?’ Reformed Review 53(2): 93-102.

Nielsen, M. and Blank, C. 2011. 'Imitation in young children: When who gets copied is more important than what gets copied.' Developmental psychology 47(4): 1050-1053.

Norton, M.I. and Gino, F. 2014. 'Rituals alleviate grieving for loved ones, lovers, and lotteries.' Journal of Experimental Psychology: General 143(1): 266-272.

Over, H. and Carpenter, M. 2012. 'Putting the social into social learning: explaining both selectivity and fidelity in children's copying behavior.' Journal of Comparative Psychology 126(2): 182192.

Over, H. and Carpenter, M. 2013. 'The social side of imitation.' Child Development Perspectives 7(1): 6-11.

Quakers in Britain, 'How Quakers Worship', from: https://www.quaker.org.uk/aboutquakers/our-faith/how-quakers-worship [accessed on 15/08/2018].

Reddish, P., Fischer, R. and Bulbulia, J. 2013. 'Let's dance together: synchrony, shared intentionality and cooperation.' PloS one 8(8): e71182.

Reddy, V. 1996. 'Omitting the second person in social understanding.' Behavioral and Brain Sciences 19(1): 140-141.

Reddy, V. 2008. How Infants Know Minds. Harvard University Press.

Risko, E. and Kingstone, A. 2011. 'Eyes wide shut: implied social presence, eye tracking and attention.' Attention, Perception \& Psychophysics 73(2): 291-296.

Scaife, M. and Bruner, J. 1975. 'The capacity for joint visual attention in the infant.' Nature 253(5489): 265-266.

Schilbach, L., Timmermans, B., Reddy, V., Costall, A., Bente, G., Schlicht, T., and Vogeley, K. 2013. 'Toward a second-person neuroscience.' Behavioral and Brain Sciences 36(4): 393-414.

Searle, J.R. 1990. 'Collective intentions and actions.' Intentions in Communication, MIT Press: 401415.

Searle, John. 2010. Making the social world: The structure of human civilization. Oxford University Press.

Shteynberg, Garriy. 2015. 'Shared attention.' Perspectives on Psychological Science 10.5: 579-590.

Shteynberg, Garriy. 2017. 'A Collective Perspective: Shared Attention and the Mind.' Current opinion in psychology 23: 93-97. 
Shyteynberg, G. and Apfelbaum, E.P. 2013. 'The power of shared experience: simultaneous observation with similar others facilitates social learning.' Social Psychological and Personality Science 4(6): 738-744.

Shteynberg, G. and Galinsky, A.D., 2011. 'Implicit coordination: Sharing goals with similar others intensifies goal pursuit.' Journal of Experimental Social Psychology 47(6): 1291-1294.

Siposova, B., Carpenter, M. Forthcoming. 'A New Look at Joint Attention and Common Knowledge.'

Sperber, D. and Wilson, D. 1995. Relevance: Communication and cognition (2 ${ }^{\text {nd }}$ edition). Blackwell.

Spilka, B. and K.L. Ladd. 2012. The Psychology of Prayer: A Scientific Approach. New York: Guildford Press.

Stump, Eleonore. 1979. 'Petitionary prayer.' American Pbilosophical Quarterly 16, no. 2: 81-91.

Taylor, C. 1985. 'Theories of Meaning.' In C. Taylor, Philosophical papers: Volume 1, Human agency and language, Cambridge University Press: 248-292.

Tollefsen, Deborah, and Dale, Rick. 2012. 'Naturalizing joint action: A process-based approach.' Philosophical Psychology 25.3: 385-407.

Tomasello, M. 1995. 'Joint Attention As Social Cognition.' In C. Moore, and P. Dunham, Joint Attention: Its Origins and Role in Development. Hillsdale, New Jersery: Lawrence Erlbaum Associates, 1990: 103-130.

Tomasello, Michael. 2013. A Natural History of Human Thinking. Harvard University Press.

Tomasello, Michael; Carpenter, Malinda; Call, Josep; Behne, Tanya and Moll, Henrike. 2005. 'In search of the uniquely human.' Behavioral and Brain Sciences, 28(5), 721-727.

Tribble, E. B. and Keene, N. 2011. Cognitive ecologies and the history of remembering: Religion, education and memory in early modern England. Palgrave Macmillan.

Tuomela, Raimo. 2013. Social ontology: Collective intentionality and group agents. Oxford University Press.

Ulanov, A.B. and B. Ulanov. 1982. Primary Speech: A Psychology of Prayer. Atlanta: John Knox Press.

Underhill, Evelyn, Worship, 1936.

Užgiris, I.C. 1981. 'Two functions of imitation during infancy.' International Journal of Behavioral Development 4(1): 1-12.

von Zimmermann, Jorina, Staci Vicary, Matthias Sperling, Guido Orgs, and Daniel C.

Richardson. 2018. 'The choreography of group affiliation.' Topics in cognitive science 10(1): 80-94.

Walton, G.M., Cohen, G.L., Cwir, D. and Spencer, S.J. 2012. 'Mere belonging: The power of social connections.' Journal of personality and social psychology 102(3): 513-532. 
Watson-Jones, R.E. and Legare, C.H. 2016. 'The Social Functions of Group Rituals.' Current Directions in Psychological Science 25(1): 42-46.

Watts, F. 2017. Psychology, Religion, and Spirituality: Concepts and Applications. Cambridge: Cambridge University Press.

Wen, N.J., Herrmann, P.A. and Legare, C.H. 2016. 'Ritual increases children's affiliation with ingroup members.' Evolution and Human Behavior 37(1): 54-60.

Whitehouse, H. and Lansman, J. A. 2014. 'The ties that bind us: Ritual, fusion and identification.' Current Anthropology 55(6): 674-683.

Zahavi, D. 2015. 'You, me, and we: The sharing of emotional experiences.' Journal of Consciousness Studies 22(1-2): 84-101.

Zahavi, D. and Satne, G. 2015. 'Varieties of Shared Intentionality.' In J. Bell, A. Cuttrofello, and P. Livingston, Beyond the continental-analytic divide: Pluralist philosophy in the twenty-first century.

Routledge. 


\section{NOTES}

${ }^{1}$ For literature in theology and philosophy of religion on prayer, see, for instance, Brümmer (1984), Stump (1978; 1984) and Howard-Snyder and Howard-Snyder (2010). There have also been a number of psychological works on prayer. See, for instance, Spilka and Ladd (2012), Ulanov and Ulanov (1982) and Watts (2017).

${ }^{2}$ See, for instance, Giordan and Woodhead (eds., 2015), Giordan (2011).

3 See, for instance, Humphrey and Laidlaw (1994), Whitehouse \& Lanman, (2014).

${ }^{4}$ See, for instance, Fabian (2015).

${ }^{5}$ Note (as an anonymous referee points out to us) that Shteynberg's concept of sharedness dovetails with some earlier work on the psychology of prayer. Spilka and Ladd talk about prayer providing a sense of connectedness between those one is praying alongside $(2012,44)$, which they suggest, can play an important role in the shaping of 'attitudes and values' $(2012,44)$ within a community.

${ }^{6}$ For instance, see Myer's (1999; see also his chapter in Jeeves and Ludwig (2018)) critiques of the methodology of the 'Harvard Prayer Experiment' (Benson et al., 2006).

${ }^{7}$ From a communications perspective Baesler and colleagues (Baesler, 1999; Baesler and Ladd, 2009; Baesler, Lindall and Lauricella, 2011) have also investigated the significance of different prayer contexts.

8 This example aligns well with Spilka and Ladd's account of the 'inward', 'upward', 'outward' model of prayer (2012, 27, 47); prayer, on this model, involves seeking personal transformation (inward), being influenced by others (outward), as well as relating to God (upward).

${ }^{9}$ See also Ladd and Spilka (2014) on this point. With thanks to an anonymous referee for raising this point.

${ }^{10}$ See Searle (1990, 2010); Bratman (2013); and Tuomela (2013) for the key positions in the debate.

${ }^{11}$ See Akhtar and Gernsbacher (2008) and Botero (2016).

${ }^{12}$ For more detailed accounts that take a second-person perspective, see Gómez (1996; 2005), Moore and Barresi (2017), Reddy (1996; 2008) and Schilbach et al (2013).

13 This notion of sharedness appears under different terms, such as a sense of something being 'between us' (Taylor, 1985) or 'mutually manifest' (Sperber and Wilson, 1995).

${ }^{14}$ See Siposova and Carpenter (forthcoming).

15 See de Bruin et al. (2012).

${ }^{16}$ See Gallotti et al (2017) and Tollefson and Dale (2012).

${ }^{17}$ A recent psychological discussion of corporate worship and psychology can be found in Brown and Strawn (2012).

18 See Searle (1995) and Tomasello (1999).

${ }^{19}$ Campbell, 2005; Gallagher, 2011.

${ }^{20}$ Whitehouse and Lanman, 2014.

21 Chwe, 2001.

22 See Heubner (2013) and Tribble and Keene (2011) on this point.

${ }^{23}$ In support of this point, see Shteynberg $(2015,583)$ for a collection of evidence that sharing attention improves memory recall of the target of attention.

${ }^{24}$ Though see Zahavi and Satne (2015) on the importance of both individual autonomy and a sense of 'We' in collective activity.

${ }^{25}$ See Codrons, Bernardi, Vandoni and Bernardi (2014), Hove and Risen (2009), Reddish, Fischer and Bulbulia (2013) and von Zimmerman, Vicary, Sperling, Orgs and Richardson (2018) for evidence for the connection between affiliation and synchronised movement in pairs and groups.

${ }^{26}$ See Chartrand and Bargh (1999), Lakin, Jefferis, Cheng and Chartrand (2003) for discussion of social mimicry ('The Chameleon Effect') and its role in both creating affiliation between individuals and for indicating affiliation. See also Chartrand and van Baaren (2009) for a comprehensive review of the causes and effects of mimicry. For recent research on intentional imitation and its relation to affiliation and group membership dynamics, see Buttleman, Zymj, Daum and Carpenter (2013), Nielsen and Blank (2011) and Over and Carpenter (2012; 2013). ${ }^{27}$ With thanks to two anonymous referees for raising these important questions for future research. 